\title{
Intellectual Capital and Operational Excellence: An Influential Assessment
}

\author{
Pavitra Dhamija \\ Industrial Psychology and People Management, \\ College of Business and Economics, \\ University of Johannesburg, Johannesburg, South Africa. \\ E-mail:pavitradhamija@gmail.com; pdhamija@uj.ac.za
}

(Received October 31, 2019; Accepted June 14, 2020)

\begin{abstract}
Competent intellectual capital is one of the most essential wealth that an organization requires in the present era of cutthroat competition. Operations management is nothing but management of operational processes in every big and small organization, and such activities constitute a major chunk of all organizational activities. Therefore, the present work targets to explore the association between intellectual capital and operational excellence, review of already conducted studies in the said area, and future directions through systematic literature review process. A total number of 165 articles provided by Scopus database (2010 to 2019) is used for analysis and interpretation. Bibliometric analysis and network analysis deliver significant clusters (operations management and optimization; intellectual capital and intellectual investment; knowledge management and decision support system; strategic planning and resource allocation; sustainable operations management and performance standards; behavioural research and change management), which is in turn a novel contribution of this article. The study concludes with a proposed conceptual model and key take away for researchers, academicians, and managers.
\end{abstract}

Keywords- Intellectual capital, Operational excellence, Bibliometric analysis, Operations management, Network analysis

\section{Introduction}

Operational excellence is the key to achieve profitable operational performance. Broadly, operational excellence is dependent upon various resources not limited to financial, infrastructure and technological. However, intellectual capital/resources form the base of every other activity/process in an organization (Cheung et al., 2010; Chen and Delmas, 2011; Tan et al., 2013). Competent intellectual capital is one of the most essential wealth that an organization requires in the present era of cutthroat competition (Huang et al., 2010; Cherrafi et al., 2018; Chen et al., 2019; Dhamija et al., 2020). Efficient and wise use of intellectual capital leads to excellent operational performances (Cahill et al., 2011; Priya and Ranjith Kumar, 2015; Modrak and Soltysova, 2018; Kalaitzi et al., 2019). Effective functioning of operations department is a big achievement for every individual involved. The said phenomenon is very well present in prominent sectors that includes banking and insurance, healthcare and information. Chugani and Jung (2010), Siebers and Aickelin (2011) and Simonetti et al. (2015) opine that successful management of operations is entirely dependent upon intellectual capital of organizations. It is worthwhile to invest in intellectual capital in order to cherish excellent operational activities in return (Sarkis et al., 2010; Aloini et al., 2011; Walker et al., 2015). Simply put, intellectual capital and operational excellence are extremely important and are supposed to go hand in hand. Further, an effectual orientation of above said combination delivers sustainable competitive advantage to contemporary organizations (Chugani and Jung, 2010; Siebers and Aickelin, 2011; Simonetti et al., 2015). 
International Journal of Mathematical, Engineering and Management Sciences

Vol. 5, No. 6, 1062-1076, 2020

https://doi.org/10.33889/IJMEMS.2020.5.6.081

Keeping the given background in consideration, this work targets to explore following research questions:

RQ1: What is the relationship between intellectual capital and operational excellence?

RQ2: Is there any contribution towards intellectual capital and operational excellence, when and where?

RQ3: What are the existing trends and future directions towards intellectual capital and operational excellence?

The present study follows systematic literature review. The collected data of 165 articles from Scopus database (until 10 October 2019) is analysed by using bibliometric and network analysis. Interpretation of inferences is drawn from cluster analysis. The remaining sections of the article covers literature review, research methodology, data analysis, findings and discussion.

\section{Review of Literature}

Operations management is nothing but management of operational processes in every big and small organization that constitutes a major chunk of all organizational activities (Mahapatra et al., 2010; Skotner et al., 2011; Dubey and Gunasekaran, 2015). Intellectual capital denotes one of the most important tangible assets for every organization for effective management of resources (Jianshe and Qun, 2010; Volochienko et al., 2018; Al-Rabeeah et al., 2019). Management of operations is the central activity in various organizations. Different organizations have varied needs to increase their performance outputs, and it is not a matter of luck that an organization receives effectual intellectual resources easily (Mahapatra et al., 2010; Skotner et al., 2011; Dubey and Gunasekaran, 2015). In similar vein, Chugani and Jung (2010), Siebers and Aickelin (2011) and Simonetti et al. (2015) commented that it takes substantial time to mould an individual as per the requirements of the organization. Operations management deals with a gamut of activities in organizations (Cahill et al., 2011; Priya and Ranjith Kumar, 2015; Modrak and Soltysova, 2018; Kalaitzi et al., 2019). Anselmsson et al. (2016) and Bonadonna et al. (2019) discussed the need and role of effective trainings that prove extremely advantageous for people dealing with operational activities. Li and Yang (2010), Ahmad and Schroeder (2011) considered intellectual capital as the main element around which various operational activities revolve. The advent of technology has affected operations management in both ways i.e. good as many complex procedures are easy now, and bad because to learn technological skills to perform operational activities is in itself a big challenge (Orhorhoro et al., 2018; Aronov et al., 2019; Dhamija and Bag, 2020). Mizutani and Nakagawa (2018) and Torlak et al. (2019) highlighted the importance of required skills that an individual must possess to attain operational excellence. This article presents a review of last 10 years to understand that how intellectual capital and operational excellence connect with each other.

\section{Research Methodology and Data Statistics}

Research methodology explain the adopted research methods, here it is systematic literature review and data statistics discusses the descriptive structure of collected data.

\subsection{Initial Keywords}

Appropriate keywords constitute one of the crucial steps in the process of systematic literature reviews. Similarly, for this article the author decides to work with certain selected keywords i.e. 'Human Resource Management', 'People Management', Workforce Management', Manpower 
International Journal of Mathematical, Engineering and Management Sciences

Vol. 5, No. 6, 1062-1076, 2020

https://doi.org/10.33889/IJMEMS.2020.5.6.081

Management', Intellectual Management', Operations Management' and 'Operational Management'. In the next step, different combinations are formulated viz.;

(1) Human Resource Management AND Operations Management OR Operational Management.

(2) People Management AND Operations Management OR Operational Management.

(3) Workforce Management AND Operations Management OR Operational Management.

(4) Manpower Management AND Operations Management OR Operational Management.

(5) Intellectual Management AND Operations Management OR Operational Management.

\subsection{Initial and Refined Search Results}

Scopus database forms the base of present work as it populates the largest repository of articles (70 million, as per the information available on the Scopus website on 10 October 2019) in the form of articles, articles in press, conference papers/proceedings and books. Scholarly work by reputed publication houses (Elsevier, Emerald, Springer and Taylor and Francis) in varied areas (social sciences, information systems, business management, accounting and medicine) is found in Scopus. Initial search carried out by using different combinations of selected keywords delivered a list of 195 articles. Following which, certain filters (articles, articles in press and English language) delivered a final figure of 165 articles for analysis (refer to Table 1).

Table 1. Keyword search results: intellectual capital and operational excellence

\begin{tabular}{|c|c|c|}
\hline & Search Keywords & $\begin{array}{c}\text { Refined } \\
\text { Rearch Results } \\
\text { Rumber of Articles) } \\
\text { (Number } \\
\text { of } \\
\text { Articles) }\end{array}$ \\
\hline Human Resource Management AND Operations Management OR Operational Management & 78 & 65 \\
People Management AND Operations Management OR Operational Management & 40 & 35 \\
Workforce Management AND Operations Management OR Operational Management & 31 & 27 \\
Manpower Management AND Operations Management OR Operational Management & 26 & 22 \\
Intellectual Management AND Operations Management OR Operational Management & 20 & 16 \\
\hline Total & $\mathbf{1 9 5}$ & $\mathbf{1 6 5}$ \\
\hline
\end{tabular}

Source: Scopus Database2010 to 2019 (10 October) and Authors' Compilation

\subsection{Descriptive Statistics}

Descriptive statistics elaborates the basic facts related to selected articles (intellectual capital and operational excellence) in terms of their annual production, journal-wise figures, affiliation status, top countries, authors, funding agencies and subject classification while considering information received from Scopus database. With respect to annual output of articles (refer to Table 2), maximum work has been contributed in 2014 (27), 2016 (22), 2018 (20), 2015 and 2019 (18) and 2017 (16). This signals that more attention is required towards selected area of research.

Table 3 explains the university-wise contribution towards research related to intellectual capital and operational excellence. Majorly, São Paulo State University (03), University of Massachusetts Dartmouth (03), University of Kent (03), University of Alicante Polytechnic School (03), Agenzia Spaziale Italiana (03) and Thales Alenia Space Italia (03). It is a good indicator for academicians to understand where they stand in this line of research and how they can move in parallel to other universities/institutions. 
International Journal of Mathematical, Engineering and Management Sciences

Vol. 5, No. 6, 1062-1076, 2020

https://doi.org/10.33889/IJMEMS.2020.5.6.081

Table 2. Annual publications: intellectual capital and operational excellence

\begin{tabular}{lc}
\hline Year & Number of Articles \\
\hline $2019^{*}$ & 18 \\
2018 & 20 \\
2017 & 16 \\
2016 & 22 \\
2015 & 18 \\
2014 & 27 \\
2013 & 14 \\
2012 & 10 \\
2011 & 11 \\
2010 & 09 \\
\hline
\end{tabular}

Source: Scopus Database2010 to 2019 (10 October) and Authors' Compilation;*Until 10 October 2019

Table 3. Affiliation-wise publications: intellectual capital and operational excellence

\begin{tabular}{lc}
\hline University/Institution & Number of Articles \\
\hline São Paulo State University & 03 \\
University of Massachusetts Dartmouth & 03 \\
University of Kent & 03 \\
University of Alicante Polytechnic School & 03 \\
Agenzia Spaziale Italiana & 03 \\
Thales Alenia Space Italia & 03 \\
Shermco Industries & 02 \\
AVO Training Institute & 02 \\
HP Critical Facilities Services & 02 \\
University Utara Malaysia & 02 \\
\hline
\end{tabular}

Source: Scopus Database2010 to 2019 (10 October) and Authors' Compilation

The journal-wise analysis indicates top journals who are accepting work in the selected area (refer to Table 4). Top 10 journals in the last 10 years of time include Journal of Cleaner Production (06), Journal of the International Academy for Case Studies (05), International Journal of Production Research (04), Journal of Operations Management (04) and IOP Conference Series Materials Science and Engineering (03). This interpretation confirms the popularity of a journal for existing and future researches.

Table 4. Journal-wise publications: intellectual capital and operational excellence

\begin{tabular}{lc}
\hline Journal & Number of Articles \\
\hline Journal of Cleaner Production & 06 \\
Journal of the International Academy for Case Studies & 05 \\
International Journal of Production Research & 04 \\
Journal of Operations Management & 04 \\
IOP Conference Series Materials Science and Engineering & 03 \\
Procedia Engineering & 03 \\
WIT Transactions on Information and Communication & 03 \\
Technologies & 02 \\
International Journal of Organizational Analysis & 02 \\
International Journal of Quality and Reliability Management & 02 \\
International Journal of Systems Assurance Engineering and & 01 \\
Management & \\
Cognition Technology and Work & \\
Source: Scopus Database2010 to 2019 (10 October) and Authors' Compilation
\end{tabular}


International Journal of Mathematical, Engineering and Management Sciences

Vol. 5, No. 6, 1062-1076, 2020

https://doi.org/10.33889/IJMEMS.2020.5.6.081

Assessing the research performance/output of various countries has always been a choice of authors. In similar vein, this article also explores which country is working towards intellectual capital and operational excellence. Table 5 discusses the list of top 10 countries i.e. United States (44), China (17), United Kingdom (17), Italy (13) and Australia (12). It is an indication for other countries to start researching in this direction.

Table 5. Publications of top 10 countries: intellectual capital and operational excellence

\begin{tabular}{lc}
\hline Country & Number of Articles \\
\hline United States & 44 \\
China & 17 \\
United Kingdom & 17 \\
Italy & 13 \\
Australia & 12 \\
Brazil & 09 \\
Spain & 08 \\
Canada & 07 \\
India & 07 \\
France & 05 \\
\hline Source: Scopus Database2010 to 2019 (10 October) and Authors' Compilation
\end{tabular}

Source: Scopus Database2010 to 2019 (10 October) and Authors' Compilation

Intellectual capital and operational excellence are important in every field of work. None of the areas are left untouched without human intervention and operational activities. Likewise, different subjects also consider these areas as important variables to research. Topmost subjects include (refer to Table 6) engineering (87), business, management, and accounting (76), computer science (35), decision science (28) and energy (19).

Table 6. Subject-wise publications: intellectual capital and operational excellence

\begin{tabular}{lc}
\hline Subject & Number of Articles \\
\hline Engineering & 87 \\
Business, Management, and Accounting & 76 \\
Computer Science & 35 \\
Decision Sciences & 28 \\
Energy & 19 \\
Earth and Planetary Sciences & 13 \\
Social Sciences & 13 \\
Environmental Sciences & 11 \\
Material Science & 09 \\
Chemical Engineering & 05 \\
\hline
\end{tabular}

Source: Scopus Database2010 to 2019 (10 October) and Authors' Compilation

Research funding is a big support for researcher's (research projects, consultancy projects, doctoral and post-doctoral academic fellowships and other related activities). In last 10 years of time, prominent funding agencies providing financial support towards selected area of research includes National Natural Science Foundation of China (08), City University of Hong Kong (02), AUTO21 Network of Centres of Excellence (01), Advanced Scientific Computing Research (01) and Beijing Higher Education Young Elite Teacher Project (01) (refer to Table 7). 
International Journal of Mathematical, Engineering and Management Sciences

Vol. 5, No. 6, 1062-1076, 2020

https://doi.org/10.33889/IJMEMS.2020.5.6.081

Table 7. Funding agencies: intellectual capital and operational excellence

\begin{tabular}{lc}
\hline Funding Agency & Number of Articles \\
\hline National Natural Science Foundation of China & 08 \\
City University of Hong Kong & 02 \\
AUTO21 Network of Centres of Excellence & 01 \\
Advanced Scientific Computing Research & 01 \\
Beijing Higher Education Young Elite Teacher Project & 01 \\
China Scholarship Council & 01 \\
National Council for Scientific and Technological Development & 01 \\
Engineering and Physical Sciences Research Council & 01 \\
European Society for Paediatric Endocrinology & 01 \\
Fred Hutchinson Cancer Research Center & 01 \\
\hline Source: Scopus Database2010 to 2019 (10 October) and Authors' Compilation
\end{tabular}

Source: Scopus Database2010 to 2019 (10 October) and Authors' Compilation

\section{Data Analysis}

Bibliometric analysis and network analysis are used to interpret data received from Scopus

database.

\subsection{Bibliometric Analysis}

BibExcel software is used to carry out bibliometric analysis. It is one of the methods to pursue systematic literature reviews. The results are received as topmost authors, keywords and searched words with respect to selected area of research, here it is intellectual capital and operational excellence. Eventually, .Net file is generated to be used for network analysis.

\subsubsection{Topmost Author(s)}

Although, several authors are working in the selected area of research, yet topmost are only a few. The list of top 10 authors who have contributed towards intellectual capital and operational management is shared below (refer to Table 8). Cheung et al. (2010), Dubey and Gunasekaran (2015), Orhorhoro et al. (2018), Sarkis et al. (2010) and Aloini et al. (2011) are the main leads (refer to Table 8). The work contributed by them can be consulted for better understanding of concepts.

Table 8. Top 10 authors: intellectual capital and operational excellence

\begin{tabular}{lc}
\hline Author & Number of Articles Published \\
\hline Cheung et al. (2010) & 03 \\
Dubey and Gunasekaran (2015) & 03 \\
Orhorhoro et al. (2018) & 03 \\
Sarkis et al. (2010) & 02 \\
Aloini et al. (2011) & 02 \\
Ahmad and Schroeder (2011) & 02 \\
Priya and Ranjith Kumar (2015) & 02 \\
Volochienko et al. (2018) & 02 \\
Mizutani and Nakagawa (2018) & 02 \\
Torlak et al. (2019) & 02 \\
\hline Source: Scopus Database2010 to 2019 (10 October) and Authors' Compilation
\end{tabular}


International Journal of Mathematical, Engineering and Management Sciences

Vol. 5, No. 6, 1062-1076, 2020

https://doi.org/10.33889/IJMEMS.2020.5.6.081

\subsubsection{Keyword Statistics}

Keywords are the real source to increase citations for a particular domain. Suitable keywords are the key to increase the popularity of a topic. In a similar vein, the most searched keywords with respect to intellectual capital and operational management (refer to Table 9) include human resource management (121), operations management (37), knowledge management (21), workforce management (20) and sustainable operations management (17).

Table 9. Top 10 keywords: intellectual capital and operational excellence

\begin{tabular}{lc}
\hline Keywords & Frequency \\
\hline Human Resource Management & 121 \\
Operations Management & 37 \\
Knowledge Management & 21 \\
Workforce Management & 20 \\
Sustainable Operations Management & 17 \\
Operational Management & 14 \\
Decision Support Systems & 12 \\
Resource Allocation & 11 \\
Information Management & 10 \\
Behavioral Research & 09 \\
\hline Source: Scopus Database2010 to 2019 (10 October) and Authors' Compilation
\end{tabular}

Source: Scopus Database2010 to 2019 (10 October) and Authors' Compilation

\subsubsection{Common Search Words}

Alike keywords, every topic is searched by using certain specific words, that are not keywords, but they are directly or indirectly related with the selected area of area of research. For intellectual capital and operational excellence, such words include (refer to Table 10) human resources (129), performance standards (101), risk management (78), performance measures (61) and decision support systems (47).

Table 10. Top 10 commonly search words: intellectual capital and operational excellence

\begin{tabular}{lc}
\hline Search Words & Frequency \\
\hline Human Resources & 129 \\
Performance Standards & 101 \\
Risk Management & 78 \\
Performance Measures & 61 \\
Decision Support Systems & 47 \\
Optimization & 28 \\
Strategic Planning & 15 \\
Change Management & 12 \\
Information Management & 09 \\
Intellectual Investment & 07 \\
\hline Source: Scopus Database2010 to 2019 (10 October) and Authors' Compilation
\end{tabular}

Source: Scopus Database2010 to 2019 (10 October) and Authors' Compilation

\subsection{Network Analysis}

Network analysis is the following step of bibliometric analysis. It relates to citation statistics of articles produced towards a particular domain. The more the citations, the better it is for the popularity of both i.e. article and respective author(s). It extends detailed understanding that who 
International Journal of Mathematical, Engineering and Management Sciences

Vol. 5, No. 6, 1062-1076, 2020

https://doi.org/10.33889/IJMEMS.2020.5.6.081

is working for a particular topic. The .Net file created by BibExcel is supplied to Gephi, and is further interpreted to receive results in the form of citation and co-citation with PageRank values.

\subsubsection{Citation and PageRank Analysis}

Citation analysis is the source to understand the goodness and viability of a particular area of research. PageRank analysis confirms the total number of visits by several readers towards a particular article. Top author(s) based on citation and PageRank analysis for intellectual capital and operational excellence comprise of Koehne et al. (2010); Chongping (2011); Matthews and Marzec (2012); Bourne et al. (2013); Koltai et al. (2014) (refer to Table 11). The contributions enable good reference material for future studies.

Table 11. Top 10 articles based on PageRank analysis: intellectual capital and operational excellence

\begin{tabular}{lcc}
\hline Author(s) & PageRank & Citation \\
\hline Koehne et al. (2010) & 0.000513 & 61 \\
Chongping (2011) & 0.000248 & 35 \\
Matthews and Marzec (2012) & 0.000110 & 10 \\
Bourne et al. (2013) & 0.000731 & 08 \\
Koltai et al. (2014) & 0.000692 & 08 \\
Wang (2015) & 0.000145 & 07 \\
Munoz and Bastian (2016) & 0.000552 & 07 \\
Guo et al. (2017) & 0.000692 & 05 \\
Shisheng et al. (2018) & 0.000258 & 04 \\
Mou and Robb (2019) & 0.000448 & 02 \\
\hline Source: Scopus Database2010 to 2019 (10 October) and Authors' Compilation &
\end{tabular}

\subsubsection{Co-citation and Cluster Analysis}

The next step after citation analysis is the co-citation analysis and cluster analysis. This process elaborates the interconnection pattern among individual citations of selected articles. Gephi software allows to frame meaningful inferences. Once the .Net file is supplied to Gephi, a random image with 97 nodes and edges 1069 is produced (refer to Figure 1). Nodes represents dots (big and small) and edges convey connecting threads between nodes. In the next step, the received random image is fine-tuned to receive clusters (refer to Figure 2) by using 'Force Atlas' layout. Each cluster represents a particular theme.

Table 12 demonstrates received clusters i.e. Cluster 1 Operations Management and Optimization; Cluster 2 Intellectual Capital and Intellectual Investment; Cluster 3 Knowledge Management and Decision Support System; Cluster 4 Strategic Planning and Resource Allocation; Cluster 5 Sustainable Operations Management and Performance Standards; Cluster 6 Behavioural Research and Change Management. Every respective cluster conveys a specific theme followed by their interconnection with each other in last 10 years of time.

Cluster 1 describes importance of operations management and optimization. Operational excellence is a deadly requirement in every concern. Any organization can collapse without efficient operations management. Investigating that how optimization can prove beneficial to achieve operational excellence is the need of hour. Cluster 2 confirms that intellectual investment towards intellectual capital can result in wonders for contemporary organizations. Efficient intellectual capital is extremely essential to achieve operational excellence. Purposeful trainings can develop a fleet of mindful people as intellectual assets. Cluster 3 brings a very interesting theme of knowledge management and decision support systems. Effective decision-making is highly 
International Journal of Mathematical, Engineering and Management Sciences

Vol. 5, No. 6, 1062-1076, 2020

https://doi.org/10.33889/IJMEMS.2020.5.6.081

dependent on the possession of knowledge for a particular domain. Management of operations is full of big and small decisions, which makes it even more crucial to understand things thoroughly before finalising.

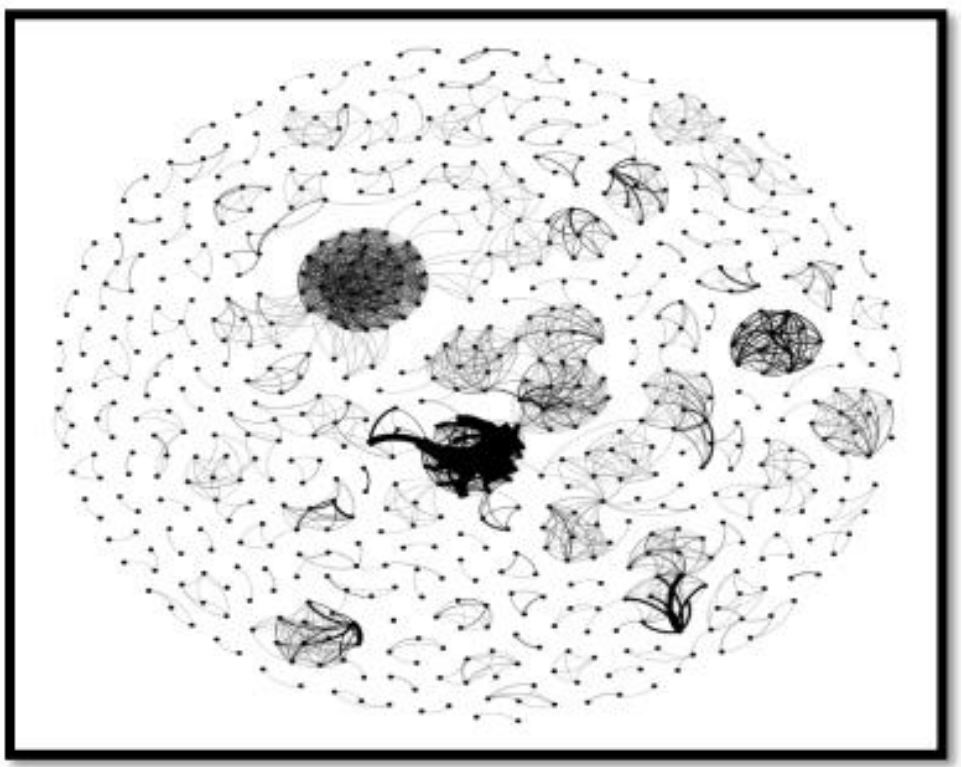

Figure 1. Force atlas layout (97 nodes and 1069 edges)

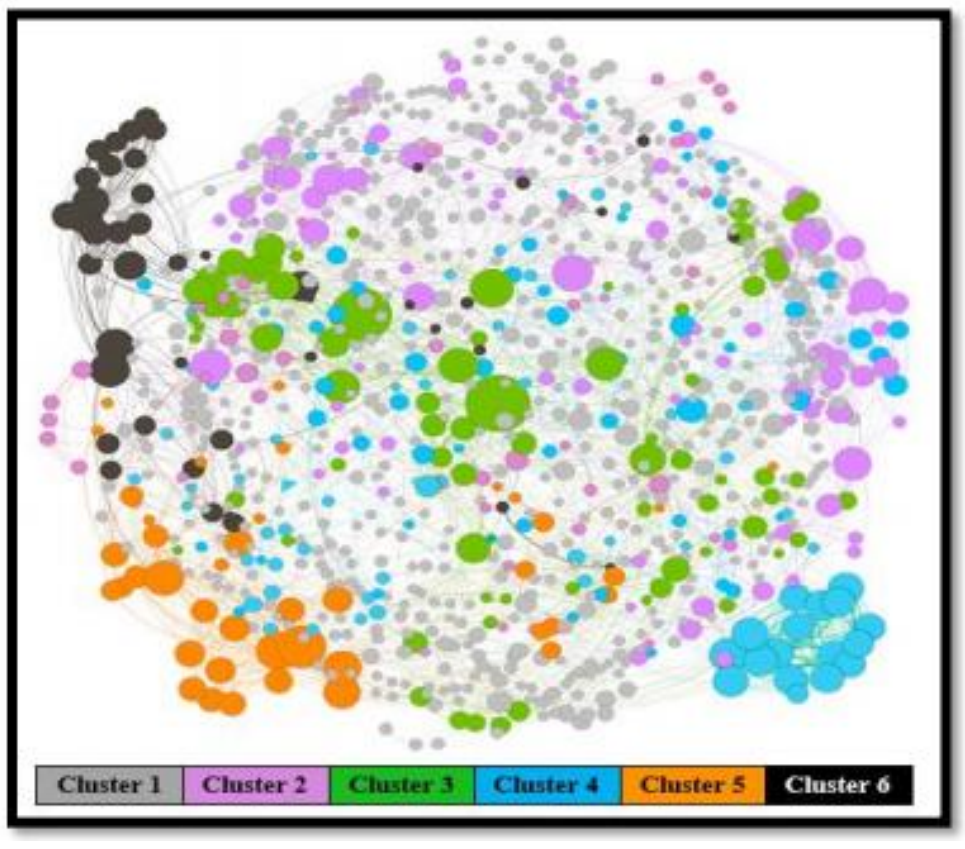

Figure 2. Force atlas structure of six clusters 
International Journal of Mathematical, Engineering and Management Sciences

Vol. 5, No. 6, 1062-1076, 2020

https://doi.org/10.33889/IJMEMS.2020.5.6.081

Table 12. Identified clusters: intellectual capital and operational excellence

\begin{tabular}{|c|c|c|}
\hline Cluster Number/Label & Current Research & Future Research Suggestions \\
\hline $\begin{array}{l}\text { Cluster 1:Operations } \\
\text { Management and } \\
\text { Optimization }\end{array}$ & $\begin{array}{l}\text {-Explains the meaning of operations management and } \\
\text { optimization. } \\
\text { (Cheung et al., 2010; Chen and Delmas, 2011; Tan et al., } \\
\text { 2013; Cherrafi et al., 2018; Chen et al., 2019) }\end{array}$ & $\begin{array}{l}\text { Recommended to explore the } \\
\text { relationship between operations } \\
\text { management and optimization. }\end{array}$ \\
\hline $\begin{array}{l}\text { Cluster 2:Intellectual } \\
\text { Capital and Intellectual } \\
\text { Investment }\end{array}$ & $\begin{array}{l}\text {-Discusses the association between intellectual capital and } \\
\text { intellectual investment. } \\
\text { (Huang et al., 2010; Cahill et al., 2011; Priya and Ranjith } \\
\text { Kumar, 2015; Modrak and Soltysova, 2018; Kalaitzi et al., } \\
\text { 2019) }\end{array}$ & $\begin{array}{l}\text { An analysis that how intellectual } \\
\text { investment can fetch maximum benefits } \\
\text { is advised. }\end{array}$ \\
\hline $\begin{array}{l}\text { Cluster 3:Knowledge } \\
\text { Management and } \\
\text { Decision Support System }\end{array}$ & $\begin{array}{l}\text {-Confirms that knowledge management and decision } \\
\text { support systems go hand in hand. } \\
\text { (Li and Yang, 2010; Ahmad and Schroeder, 2011; } \\
\text { Sparrow and Cooper, 2014; Anselmsson et al., 2016; } \\
\text { Bonadonna et al., 2019) }\end{array}$ & $\begin{array}{l}\text { Intelligent decisions are possible only } \\
\text { with adequate knowledge. An approach } \\
\text { towards effective knowledge } \\
\text { management is highly recommended. }\end{array}$ \\
\hline $\begin{array}{l}\text { Cluster 4:Strategic } \\
\text { Planning and Resource } \\
\text { Allocation }\end{array}$ & $\begin{array}{l}\text {-Elaborates the importance of strategic planning while } \\
\text { allocating intellectual resources. } \\
\text { (Mahapatra et al., 2010; Skotner et al., 2011; Dubey and } \\
\text { Gunasekaran, 2015; Orhorhoro et al., 2018; Aronov et al., } \\
\text { 2019) }\end{array}$ & $\begin{array}{l}\text { Intellectual resources forms the base of } \\
\text { every big or small organization. A deep } \\
\text { look is needed to understand allocation of } \\
\text { human capital especially in the era of } \\
\text { Industry 4.0. }\end{array}$ \\
\hline $\begin{array}{l}\text { Cluster 5:Sustainable } \\
\text { Operations Management } \\
\text { and Performance } \\
\text { Standards }\end{array}$ & $\begin{array}{l}\text {-Discusses the meaning of sustainable operations } \\
\text { management and performance standards. } \\
\text { (Sarkis et al., 2010; Aloini et al., 2011; Walker et al., 2015; } \\
\text { Volochienko et al., 2018; Al-Rabeeah et al., 2019) }\end{array}$ & $\begin{array}{l}\text { Assessment that how performance } \\
\text { standards contribute towards sustainable } \\
\text { operational excellence is highly advised. }\end{array}$ \\
\hline $\begin{array}{l}\text { Cluster 6: Behavioural } \\
\text { Research and Change } \\
\text { Management }\end{array}$ & $\begin{array}{l}\text {-Confirms a strong connection between human behaviour } \\
\text { and change management. } \\
\text { (Chugani and Jung, 2010; Siebers and Aickelin, 2011; } \\
\text { Simonetti et al., 2015; Mizutani and Nakagawa, 2018; } \\
\text { Torlak et al., 2019) }\end{array}$ & $\begin{array}{l}\text { Adjusting human behaviour is the key to } \\
\text { accept change. Intellectual capital must } \\
\text { be trained accordingly. }\end{array}$ \\
\hline
\end{tabular}

Source: Scopus Database 2010 to 2019 (10 October) and Authors' Compilation

Cluster 4 elaborates the importance of strategic planning with respect to intellectual allocation of resources. Intellectual resources are the root on which every organization stand and flourish. Absence of strategic planning for intelligent allocation of resources can push any organization in loss. Cluster 5 performance standards significantly contribute towards success or failure of an organization. Success of contemporary organizations revolves around their sustainable existence. A deep look into the measures that can result in sustainable operations management is highly needed. Cluster 6 discusses association between behavioural research and change management. Human behaviour is one of the most complex aspect to understand, and change management cannot be ignored. Training intellectual capital to accept change is the need of the hour. Accepting change is a step towards success, which can be achieved with positive mental cognition.

\section{Discussion and Contribution}

Present work is a unique contribution towards existing body of knowledge. The availability of limited number of articles with respect to intellectual capital and operational excellence justifies that not much work is produced in this line of research. Understanding a particular area in terms that what has already happened in the last 10 years of time and scope for future is the novel significance of this article. 
International Journal of Mathematical, Engineering and Management Sciences

Vol. 5, No. 6, 1062-1076, 2020

https://doi.org/10.33889/IJMEMS.2020.5.6.081

Theoretically, the article answers framed research questions. It is evidenced that there exists an association between intellectual capital and its allied areas with operations management or operational excellence. Further, which author has contributed the most, which country is most actively producing, what can be explored in future and other similar issues are discussed in length. An interesting element is the interconnection of various clusters. Cluster 1 Operations Management and Optimization is common to all other clusters, as optimization is the key for everything. The interconnection between Cluster 3 Knowledge Management and Decision Support System, Cluster 4 Strategic Planning and Resource Allocation, and Cluster 5 Sustainable Operations Management and Performance Standards conveys sensitive association because sustainability can be achieved only with adequate knowledge management and strategic initiatives. The second group of Cluster 2 Intellectual Capital and Intellectual Investment and Cluster 6 Behavioural Research and Change Management conveys the importance of investment towards humans.

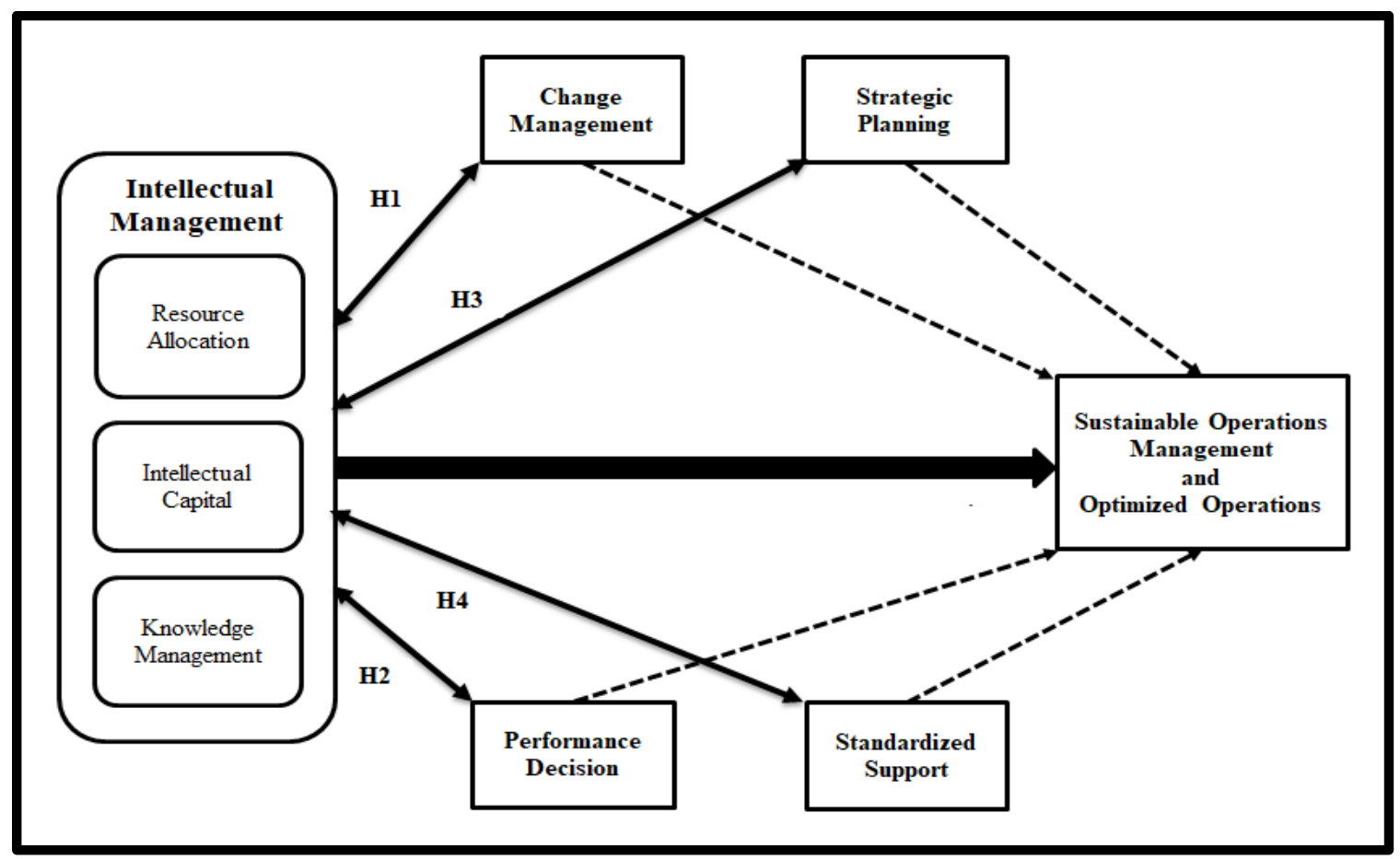

Figure 3. Proposed conceptual model

Managers and policy makers constitute an important decision-making authority in various organizations across sectors, and operations management is one of the crucial departments. Firstly, it becomes very important for the managers to understand the right mix of people who not only can work together in cohesiveness. Secondly, the upcoming of technology is undoubtedly delivering benefits to the people at large; however, it is also bringing technological challenges. Many trainings are required to make people ready to accept this change. Managers and policy makers are advised to overview the peculiarities of operational activities before deploying people. Thirdly, the acceptance of change is not inevitable by everyone. At times, an individual might take long to accept the desired change. Operational excellence is all about adopting suitable change at 
International Journal of Mathematical, Engineering and Management Sciences

Vol. 5, No. 6, 1062-1076, 2020

https://doi.org/10.33889/IJMEMS.2020.5.6.081

appropriate time to gain competitive advantage. Eventually, adopting of all identified themes can serve real achievement for the managers and policy makers. Until and unless each cluster is assessed and analysed thoroughly by concerned authorities, the real advantages cannot be secured.

Given the above background and author's understanding, a conceptual model (refer to Figure 3) based on identified clusters is proposed for future researches. The testing of proposed model will confirm if intellectual management leads to sustainable operations management and optimized operations while considering change management, strategic planning, performance decision and standardized support in various hypothetical associations. The said model, if tested, can deliver meaningful and significant results in this domain.

\subsection{Limitations of the Study}

Every research possesses certain limitations. Similarly, in this article, the selection of keywords is at the discretion of the author. Secondly, apart from BibExcel and Gephi, systematic literature reviews are possible with other tools as well, which might prove slight variation in the existing results.

\section{Conclusion}

The article provides an interesting theme for the researchers, academicians and policy makers. It extends a good food for thought to pursue connected researches for future scope of work. To the author's surprise, the selected variables i.e. intellectual capital and operations management are not new, yet the author could receive less data from Scopus database in the last 10 years of time. The importance of said combinations are very well reflected in the identified predominant themes. Merely publishing articles in not enough. The review of already published work enables meaningful outcomes and interesting directions to be explored, and the same is addressed by this article.

\section{Conflict of Interest}

The author declares no conflict of interest is associated with this article.

\section{Acknowledgement}

The author extends sincere thanks to the Department of Industrial Psychology and People Management, College of Business and Economics, University of Johannesburg for facilitating necessary resources to pursue this study, and to the respective editors and reviewers for investing their precious time and providing advise which has further improved the quality of present article.

\section{References}

Ahmad, S., \& Schroeder, R.G. (2011). Knowledge management through technology strategy: implications for competitiveness. Journal of Manufacturing Technology Management, 22(1), 6-24.

Aloini, D., Martini, A., \& Pellegrini, L. (2011). A structural equation model for continuous improvement: a test for capabilities, tools and performance. Production Planning \& Control, 22(7), 628-648.

Al-Rabeeah, M., Munapo, E., Al-Hasani, A., Kumar, S., \& Eberhard, A. (2019). Computational enhancement in the application of the branch and bound method for linear integer programs and related models. International Journal of Mathematical, Engineering and Management Sciences, 4(5), 11401153. 
International Journal of Mathematical, Engineering and Management Sciences

Vol. 5, No. 6, 1062-1076, 2020

https://doi.org/10.33889/IJMEMS.2020.5.6.081

Anselmsson, J., Bondesson, N., \& Melin, F. (2016). Customer-based brand equity and human resource management image: do retail customers really care about HRM and the employer brand?. European Journal of Marketing, 50(8), 1185-1208.

Aronov, J., Carrion, A., Papic, L., Galkina, N., Aggrawal, D., \& Anand, A. (2019) Standards development and innovative products. When should standards be prepared?. International Journal of Mathematical, Engineering and Management Sciences, 4(5), 1081-1093.

Bonadonna, A., Alfiero, S., Cane, M., \& Gheribi, E. (2019). Eating hamburgers slowly and sustainably: the fast food market in north-west Italy. Agriculture, 9(4), 77-89.

Bourne, M., Pavlov, A., Franco-Santos, M., Lucianetti, L., \& Mura, M. (2013). Generating organisational performance: the contributing effects of performance measurement and human resource management practices. International Journal of Operations \& Production Management, 33(12), 1599-1622.

Cahill, J., Mc Donald, N., \& Losa, C.G. (2011). Intelligent planning and the design of a new risk-based, intelligent flight plan. Cognition, Technology \& Work, 13(1), 43-66.

Chen, C.M., \& Delmas, M. (2011). Measuring corporate social performance: an efficiency perspective. Production and Operations Management, 20(6), 789-804.

Chen, D., Ignatius, J., Sun, D., Zhan, S., Zhou, C., Marra, M., \& Demirbag, M. (2019). Reverse logistics pricing strategy for a green supply chain: A view of customers' environmental awareness. International Journal of Production Economics, 217(1), 197-210.

Cherrafi, A., Garza-Reyes, J.A., Kumar, V., Mishra, N., Ghobadian, A., \& Elfezazi, S. (2018). Lean, green practices and process innovation: a model for green supply chain performance. International Journal of Production Economics, 206 (1), 79-92.

Cheung, M.S., Myers, M.B., \& Mentzer, J.T. (2010). Does relationship learning lead to relationship value? A cross-national supply chain investigation. Journal of Operations Management, 28(6), 472-487.

Chongping, Z. (2011). On the theory of scientific management and the development of Chongqing's catering chain industry. Procedia Engineering, 15(1), 5420-5424.

Chugani, S., \& Jung, J.Y. (2010). Parout's "bone marrow drive" project management. Journal of the International Academy for Case Studies, 16(4), 1-24.

Dhamija, P., \& Bag, S. (2020). Role of artificial intelligence in operations environment: a review and bibliometric analysis. The TQM Journal, https://doi.org/10.1108/TQM-10-2019-0243. (in press).

Dhamija, P., Bedi, M., \& Gupta, M.L. (2020). Industry 4.0 and supply chain management: a methodological review. International Journal of Business Analytics (IJBAN), 7(1), 1-23.

Dubey, R., \& Gunasekaran, A. (2015). Shortage of sustainable supply chain talent: an industrial training framework. Industrial and Commercial Training, 47(2), 86-94.

Guo, H., Gao, S., Tsui, K.L., \& Niu, T. (2017). Simulation optimization for medical staff configuration at emergency department in Hong Kong. IEEE Transactions on Automation Science and Engineering, 14(4), 1655-1665.

Huang, X., Kristal, M.M., \& Schroeder, R.G. (2010). The impact of organizational structure on mass customization capability: a contingency view. Production and Operations Management, 19(5), 515-530.

Jianshe, L., \& Qun, Y. (2010, August). The analysis of human resource allocation and incentive based on JIT system. In 2010 International Conference of Information Science and Management Engineering (Vol. 2, pp. 83-86). IEEE. Xi'an, China.

Kalaitzi, D., Matopoulos, A., Bourlakis, M., \& Tate, W. (2019). Supply chains under resource pressure: strategies for improving resource efficiency and competitive advantage. International Journal of Operations and Production Management, 39(12), 1323-1354. 
International Journal of Mathematical, Engineering and Management Sciences

Vol. 5, No. 6, 1062-1076, 2020

https://doi.org/10.33889/IJMEMS.2020.5.6.081

Koehne, V., Ziliotto, V., Schiemann, J., \& Boisvert, P. (2010). ESA payload operations management on the ISS: lessons learned and challenges. In SpaceOps 2010 Conference Delivering on the Dream Hosted by NASA Marshall Space Flight Center and Organized by AIAA (p. 2349). Huntsville, Alabama.

Koltai, T., Tatay, V., \& Kalló, N. (2014). Application of the results of simple assembly line balancing models in practice: the case of a bicycle manufacturer. International Journal of Computer Integrated Manufacturing, 27(9), 887-898.

Mahapatra, S.K., Narasimhan, R., \& Barbieri, P. (2010). Strategic interdependence, governance effectiveness and supplier performance: a dyadic case study investigation and theory development. Journal of Operations Management, 28(6), 537-552.

Matthews, R.L., \& Marzec, P.E. (2012). Social capital, a theory for operations management: a systematic review of the evidence. International Journal of Production Research, 50(24), 7081-7099.

Mizutani, S., \& Nakagawa, T. (2018). Maintenance overtime policy with cumulative damage. International Journal of Mathematical, Engineering and Management Sciences, 3(2), 123-135.

Modrak, V., \& Soltysova, Z. (2018). Development of operational complexity measure for selection of optimal layout design alternative. International Journal of Production Research, 56(24), 7280-7295.

Mou, S., \& Robb, D.J. (2019). Real-time labour allocation in grocery stores: a simulation-based approach. Decision Support Systems, 12(4), 113-124.

Munoz, D.A., \& Bastian, N.D. (2016). Estimating cross-training call center capacity through simulation. Journal of Systems Science and Systems Engineering, 25(4), 448-468.

Orhorhoro, E.K., Orhorhoro, O.W., \& Atumah, E.V. (2018). Performance evaluation of design ad system biogas purification filter. International Journal of Mathematical, Engineering and Management Sciences, 3(1), 17-27.

Priya, M., \& Ranjith Kumar, P. (2015). A novel intelligent approach for predicting atherosclerotic individuals from big data for healthcare. International Journal of Production Research, 53(24), 7517-7532.

Sarkis, J., Gonzalez-Torre, P., \& Adenso-Diaz, B. (2010). Stakeholder pressure and the adoption of environmental practices: the mediating effect of training. Journal of Operations Management, 28(2), 163-176.

Shisheng, L., Liang, C., Wenzhang, H., \& Zuoshang, C. (2018, September). Research on the top design and implementation mode of intelligent power distribution room. In 2018 China International Conference on Electricity Distribution (CICED) (pp. 2375-2381). IEEE. Tianjin, China.

Siebers, P.O., \& Aickelin, U. (2011). A first approach on modelling staff proactiveness in retail simulation models. Journal of Artificial Societies and Social Simulation, 14(2), 1-16.

Simonetti, R., Ciccone, G., Ferrante, A., \& Daher, E. (2015, October). Reducing delays in document management and tooling costs of refineries and plants: a case study of risk management software development. In SPE/IATMI Asia Pacific Oil \& Gas Conference and Exhibition. Society of Petroleum Engineers. Bali, Indonesia.

Skotner, C., MacDonald, J.A., \& Bansal, R. (2011). A novel decision support system for operational management of the reservoirs of Bhakra and Beas dams. In Proceedings of the 34th World Congress of the International Association for Hydro-Environment Research and Engineering: 33rd Hydrology and Water Resources Symposium and 10th Conference on Hydraulics in Water Engineering (p. 4499). Engineers Australia.

Sparrow, P., \& Cooper, C. (2014). Organizational effectiveness, people and performance: new challenges, new research agendas. Journal of Organizational Effectiveness: People and Performance, 1(1), 2-13. 
International Journal of Mathematical, Engineering and Management Sciences

Vol. 5, No. 6, 1062-1076, 2020

https://doi.org/10.33889/IJMEMS.2020.5.6.081

Tan, K.H., Denton, P., Rae, R., \& Chung, L. (2013). Managing lean capabilities through flexible workforce development: a process and framework. Production Planning \& Control, 24(12), 1066-1076.

Torlak, N.G., Demir, A., \& Budur, T. (2019). Impact of operations management strategies on customer satisfaction and behavioral intentions at café-restaurants. International Journal of Productivity and Performance Management, https://doi.org/10.1108/IJPPM-01-2019-0001. (in press).

Volochienko, V., Falko, S., \& Postnikova, E. (2018). Recognition of the problematic situations in industrial systems with intellectual support. International Journal of Mathematical, Engineering and Management Sciences, 4(6), 1434-1447.

Walker, H., Chicksand, D., Radnor, Z., \& Watson, G. (2015). Theoretical perspectives in operations management: an analysis of the literature. International Journal of Operations \& Production Management, 35(8), 1182-1206.

Wang, C.Y. (2015). Evaluation of sports center performance using a fuzzy multi-criteria decision-making model. Journal of Testing and Evaluation, 43(6), 1372-1382.

Original content of this work is copyright $\odot$ International Journal of Mathematical, Engineering and Management Sciences. Uses under the Creative Commons Attribution 4.0 International (CC BY 4.0) license at https://creativecommons.org/licenses/by/4.0/ 